\title{
Черкасов Н.И. \\ Ограничения прав чиновников и политиков по законодательству Российской Федерации
}

Московский финансово-юридический университет

(Россия, Москва)

doi:10.18411/spc-20-03-2018-11

idsp: 000001:spc-20-03-2018-11

Регламентируя правовое положение госслужащих, государство устанавливает особые правила (запреты и ограничения). В то же самое время необходимо учитывать интересы и ценности, закрепленные в Конституции Российской Федерации.

Согласно ч. 3 ст. 55 Конституции РФ права и свободы могут ограничиваться только федеральными законами, только в той мере, в какой это необходимо в целях защиты основ конституционного строя, нравственности, здоровья, прав и законных интересов других лиц, обеспечения обороны страны и безопасности государства

Ограничения - это установленные нормами служебного права обстоятельства, при наличии или возникновении которых государственные гражданские служащие не могут проходить госслужбу и подлежат увольнению, а граждане (иностранные граждане) не могут поступить на государственной гражданской службу.

Для чего необходимы ограничения?

- для эффективного функционирования всей системы государственной гражданской службы;

- с целью пресечения противоправных действий чиновников, используя свое служебное положение;

- для обеспечения необходимого развития социальной системы.

Статья 17 регламентирует многие запреты, которые по сути являются ограничением прав гражданского служащего. Так, например, запрет осуществления предпринимательской деятельности является ограничением свободы труда, закрепленной в статье 37 Конституции РФ.

Как важная сфера государственно-управленческой деятельности государственная служба организуется на определенных началах, основах, этим придается четкий ориентир ее правовому регулированию и деятельности государственных служащих. Социально-правовые основы государственной службы образуют официально провозглашаемые приоритеты и направления общественного развития, соответствующие им установки и цели государственного строительства, а также нормативно установленные принципы и основы организации и функционирования государственной службы. Эффективность государственной службы при этом определяется тем, как, каким образом, насколько качественно она обслуживает потребности человека и помогает ему в обычной жизни. Рассматривая государственную службу как вид деятельности, необходимо отметить, что, с одной стороны, службами называются многие органы государственной исполнительной власти, а с другой - под службой понимается деятельность отдельных категорий граждан. В данном случае понятие "государственная служба" неразрывно связано с понятием "государственный служащий", причем под государственными служащими подразумеваются лица, работающие в любой государственной организации.

Исходя из вышеизложенного, на мой взгляд, для более эффективного функционирования органов государственной власти, ст. 16 ч. 1 п. 5 Федерального закона «О государственной гражданской службе Российской Федерации», необходимо изложить в следующей редакции: граждане, имеющие близкое родство или свойство с гражданским служащим (родители, супруги, дети, братья, сестры и т.д.), не могут быть приняты на гражданскую службу, а служащий не может находиться на гражданской 
службе независимо от того, находятся ли они в непосредственном подчинении одного из них другому.

Также ст. 20 ч. 1 того же Закона изложить в следующей редакции: Гражданин, претендующий на замещение должности гражданской службы, включенной в перечень, установленный нормативными правовыми актами Российской Федерации, а также гражданский служащий, замещающий должность гражданской службы, включенную в перечень, установленный нормативными правовыми актами Российской Федерации, ежегодно, не позднее 30 апреля года, следующего за отчетным, представляет представителю нанимателя сведения о своих доходах, имуществе и обязательствах имущественного характера, а также о доходах, об имуществе и обязательствах имущественного характера всех членов своей семьи о расходах и имеющемся имуществе не только близких родственников но и бывших супругов, а также лиц проживающих вместе с ними.

Государственная гражданская служба должна быть правовой, четко организованной, социально ориентированной, прочно связывать общество с государством.

$$
* * *
$$

1. Камолов С.Г. Антиконфликтология. Вопросы преподавания управленческойконфликтологии в вузах. Монография. ISBN: 978-5-906367-35-8. М.: Издательство "Международные отношения", 2016.

2. Костенников М.В., Куракин А.В., Павлюк А.В. К вопросу о понятии и методах государственного управления в административном праве // Административное и муниципальное право. 2013. № 5. С. 430-439.

3. Терминологический справочник по электронному правительству / отв. ред. М.Ю. Игитян. - М.: Фонд поддержки международных программ. 2017. — 48 с.

\section{Шаблинский П.П. \\ Виды и причины дорожно-транспортных происшествий}

doi:10.18411/spc-20-03-2018-12

Академия управления МВД России idsp: 000001:spc-20-03-2018-12

Обеспечение безопасности дорожного относится к числу значимых социальноэкономических проблем не только России и всего мира. В результате дорожнотранспортных происшествий (далее - ДТП) в разных странах ежегодно погибает более 1 млн. человек и до 50 млн. получают ранения. В случае сохранения тенденции роста аварийности к 2030 году ДТП займут пятое место среди основных причин смертности в мире.

Глобальные экономические потери, связанные с летальными исходами и травмами от ДТП, по оценкам Всемирного Банка, достигают в некоторых странах 2\% валового национального продукта, а суммарные годовые издержки превышают 500 млрд. долларов США.

К сожалению, проблема обеспечения безопасности на дорогах сохраняет свою актуальность и для России. В нашей стране в условиях продолжающегося роста уровня автомобилизации (с 2005 г. он увеличился в полтора раза и сейчас во многих городах на тысячу жителей в среднем приходится по 300 единиц автотранспорта) государству на протяжении ряда лет удалось обеспечить некоторое сокращение общего количества ДТП и пострадавших. Однако абсолютные показатели аварийности в России пока остаются высокими.

Именно ГИБДД осуществляет контольно-надзорные и профилактические функции. Сотрудники ГИБДД обеспечивают государственный технический надзор за предприятиями, имеющими на своем балансе автобусы и автомашины, 